\author{
Acta Scientifica Naturalis \\ Former Annual of Konstantin Preslavsky University - Chemistry, Physics, Biology, Geography \\ Journal homepage: http://www.shu.bg
}

Received: 30.10 .2016

Accepted: 11.01.2017

\title{
Geomorphology of outflow part Batova river valley
}

\author{
Ivalena Vulcheva-Georgieva, Svetla Stankova \\ „Episkop Konstantin Preslavski” University of Shumen, Faculty of natural sciences, Department \\ “Geography and methodology of teaching geography”Shumen, 9712 Universitetska Str. 115, E-mail; \\ ivalena_jv@mail.bg; s_stankova@abv.bg
}

\begin{abstract}
Firths are geomorphological and hydrological sites typical for flat, neutral coast of no tidal sea basins. There in the greatest extend is preserved the geological column of the correlative PleistoceneHolocene sediments. They make possible to reveal the Quaternary evolution of the contact zone ,"land - sea”. Firths are one of the most reliable indicators for the Quaternary Earth crust movements.

Along the Black Sea coast most widely are developed the firths in the north - west and the west periphery, where they form a classic firth type coast.

This report examines the results of complex studies of Batova river firth, located (developed) on the North Bulgarian Black Sea coast.
\end{abstract}

Key words: firth (liman), coastline, neutral type of coast, Quaternary movements

In this report are examined part of results obtained in the complex researches of river outflow parts within the North Bulgarian Black Sea coast. It researches geomorphological specific of a segment in our the Black Sea territories as and made attempt to reveal facts and evidence about the role of the Black Sea kettle in forming of contemporary morphological shape of the researched region.

Object of this research are Batova river outflow parts. They are part of the continental outlying which under the influence of the Black Sea kettle evolution and eustatic changes of the sea basin level.

The aim of this research is to reveal the factors and the conditions for forming Batova river outflow which represents in fact clear expressed firth.

The firths are geomorphological and hydrological objects featured for plain, neutral type coast of no tidal sea basins. From geomorphological point of view the are interested in high grade as they preserve fully the cross-section of correlative the Pleistocene-Holocene sediments. They give opportunity to reveal the Quaternary evolution in the contact zone „land - sea”. The firths are the most reliable indicators for the young and contemporary Earth crust movements.

The firth configuration almost repeats the outlines of the old, drowned during the Holocene river valleys. The forming of the firth cup is result of erosion over excavate of outflow parts in core rocks during the regressive phases of the Black Sea. That's why its alluvial deposits are regressive type. It's thickness is different for the each firth and depends of the power and speed of the flow, of the feeding mode and sedimentation features. When the flow is weak or there is movement to the land of close-grained material in the firths have deposited clay sediments enriched by bacteria. In a big flow of the firth are deposit close grained sands, alevrits and clays which have thin seasonal strata. They are enriched by organic material.

In the outflow part Batova river has chest shape form. The bank is low with long sand stripe Westward has wide forest valley named Baltata. This is the most Northward forest from longos forest on our coast.

\section{Morphohydrographical and morphometric features of the relief.}

Batova River is the only one within the coastal Dobrudga with constant water flow. It's water basin catchment is formed between Dobrudga plateau northward and Frangen one Southward. In its upper stream it's named Djezveliiska River. It starts from karst spring in Frangen plateau near Kumanovo village (hill 290 $\mathrm{m})$. It's length is $38,7 \mathrm{~km}$. In its beginning it is weak flow with slight slope and downstream it is wide to $4-5$ $\mathrm{m}$. After it flows northward and beside Batovo village takes eastward and to Obrochishte village turns southeastward till Kranevo village where it outflows.

In its upper stream the slopes are high and steep but between Batovo and Obrochishte villages they have asymmetric cross section profile. The left valley slope is three times wider than the right one. Both slopes 
have active landslides which hampers the separation of typical over flooded terraces. From other side the flood terrace is developed from Obrochishte village till its outflow. At the coast it is $2 \mathrm{~m}$ wide. There is spread Baltata lowland which represents reserve with rear plant species with dense longos forest.

In its coastal part Batova River flows southeastward. It is chest shaped with steep slopes and plain river bed. In its outflow Batova river is combined with Kranevska River. Now days this valley lowering is represented by Batova firth. It's area spreads on $13 \mathrm{~km}^{2}$ and $2 \mathrm{~km}$ inward till Obrochishte river. All firths on our coast have cuneiform shape - wide their outflow and then narrows to their upper stream. Batova firth is separated by the sea with sand spit on Nymphaean age. It concerns to open firths on our coast.

\section{Lithological - Stratigraphic and tectonic preconditions for developing of the relief.}

For its contemporary shape of Batova river valley first importance has lithological-structural substratum where they have formed. Except this lithological-stratigraphic features of the rocks have importance because of the fact from one side it is a saddle where are formed river valleys and the firth cup and from other side they are supply province.

Batova river basin is developed in the range of coastal part of Misian plate. The role of lithological factor is clear represented in mineral structure of alluvial deposits filled valley bed and firth cup. This factor has reflection in the structure of beach stripe which main component - quartz sands are result of erosion and abrasion of structured with mainly quartz Senonian and Eocene sand stones.

In geological structure of coastal part South Misian (Danube) plain are presented rocks with sediment origin - limestone, sands, clays, marls and loess in Miocene and Quaternary age.

\section{Morphology and structure of Batova firth.}

The outflow of Batova River is typical delta which has formed in result of filling of over excavate outflow with different in their genesis deposits. Today is counted active deposit of firth-flooded settlings which is result of forming the sand spit separating the outflow from the sea decreasing its influence. [1] determine the sand spit at Nymphaean age.

The river bed at the outflow has width $5 \mathrm{~m}$ alongside the left valley slope. In its flow in the sea Batova river it's flooded terrace transits to accumulative terrace in Nymphaean age high $2 \mathrm{~m}$ and wide $300 \mathrm{~m}$. On the left bank the terrace touches to the high cliff incised northward and is represented by several dunes combined to the sand spit southward. On the right slope this Nymphaean terrace touches the core rock.

The surface of the flooded terrace slightly transits to over flooded terrace wide $800 \mathrm{~m}$ spread in bigger part of the valley. It is accumulative represented by thin bed and flood facies. It has formed during the second part of Holocene ate the transgression and formation of the sand spit. In this time has begun the filling of the firth with delta and lagoon-firth deposits.

On the left valley slope of Batova river outflow near Albena resort has outlined sea terrace with height $10-15 \mathrm{~m}$ and width $150 \mathrm{~m}$ [2].

Within the valley have sea terraces on different age. They are researched and described by different authors but mainly by [2]. In their dating are used the existed correlation schemes of sea and river terraces [3].

The use of river and sea terraces in the region as morphostratigraphic levels is hard up due the spread landslide processes. They cover the terrace surfaces. It's poor the presence of accumulative materials an lead fossil fauna. It hard up the identification and dating of terrace levels. That's why many crinkle of the relief accepted as terraces are recognized by some scholars with reservations.

Except the flooded terrace of Batova river, [2] point to several small sites-remains of river terraces alongside the valley: Southern from Batovo village $(90-95 \mathrm{~m})$, beside Tsarkva village $(35 \mathrm{~m})$, between Obrochishte and Rogachevo villages $(18-20 \mathrm{~m})$ etc. The flooded accumulative terraces are widely spread onto both valley slopes on height $2-4 \mathrm{~m}$.

The oldest Tschaudinian coastal line of Black Sea is marked in outflow part of Batova river. In the Southern edge of Dobrudga plateau up to Albena resort is presented terrace site on 100-105 m height which is accepted as Tschaudinian one. Southern Kranevo village has also terrace on height $90 \mathrm{~m}$ covered with marine rubble.

Euxino-Uzunlarian terrace is weak represented. Some it's fragments are formed on height $37-40 \mathrm{~m}$ northeast from Batova river outflow. It incises in horizontal Sarmatian limestone sand rocks. The marine accumulative cover is composited by rubbles mixed with detrital limestone. On them are lied dealluvial and alluvial clays, sands and rubbles. 
The biggest footprint onto the contemporary relief is done Karangatian terraces. Northward Batova river outflow have represented incised in old landslides terraces on heights $12-14 \mathrm{~m}$ and $19 \mathrm{~m}$. In their sands and rubbles are collected fauna which prove their age.

In complex with Karangatian terraces onto the above mentioned sites are lying in well preserved remains of new Black Sea terrace on $5 \mathrm{~m}$ height from contemporary river bed.

The contemporary coastal processes at Batova river outflow have heritable feature. The accumulative mode has established in the beginning of Holocene transgression and supports the consecutive forming of coastal axis. Today in this area has $5 \mathrm{~km}$ beach which is wide $200 \mathrm{~m}$ with medium grained yellow-gray sands.

For research of structure, morphology and development of Batova river firth are drilled five rehearsal wells across it's axle. In the range from 0 to $30 \mathrm{~m}$ are represented manifold facies, alluvial-firth and marine deposits in Neweuxinian age and Holocene age after trespassing into Neogene rocks composite the base of Paleo-incise [4]. The most clear cross-section is on well 125.

The erosion activity of Paleo-Batova river has formed Paleo-incise the base of it has marked on different wells depth. The core rocks structured the firth cup are on Neogene age.

There are represent from limestone, sandstone and marls. The morphology of Palo-incise is with clear expressed asymmetry. The well 123 points depth of the core rocks in $30,5 \mathrm{~m}$ under the surface and this is the deepest point in the erosion valley in this part of the firth. In well 127 the depth of the level NeogeneQuaternary is on $10 \mathrm{~m}$ under the surface. At well 125 this depth is $26,7 \mathrm{~m}$. Use the whole information from the wells it outlined the shape of erosion valley. The width in this part is around $1650 \mathrm{~m}$. It has shape of irregular trapezoid. The left slope is highly steep but the right one is with slight incline and we can suppose the bed is developed in it [4].

The forced erosion activity at the left board can be used as a confirmation on the thesis for Eastern and North-Eastern incline of the strata. This incline is predicted the direction of river erosion activity which on the plain of drowning strata has incised into the left board of Paleo-incise.

In the base of strata cross-section of the firth over the core Neogene rocks diluted superpose the deposits with Neweuxinian age. They represent dynamic type alluvial deposits from in strata phase of accumulation. The basalt horizon is composed by different smoothed mainly limestone rubbles with grainy sand refill. The deepest point of this horizon lies around well 123 where it crosses on the interval $25,5-30 \mathrm{~m}$ but on the other side of the firth around well 127 lies on depth 9,6-10,6 m with thickness $1 \mathrm{~m}$. It impresses the thickness $7,5 \mathrm{~m}$ of Neweuxinian deposits at well 126. Onto rubble-gravel alluvial layer of $30 \mathrm{~cm}$ with slight transition they pass to alevrites with $7,2 \mathrm{~m}$ thickness.

These different facies assume a change in hydrodynamic situation in this part of water basin. From strong dynamical conditions slightly the sedimentation is done in calm probably lake environment. As proof are founded segment of shells from freshwater Molluscan fauna.

In lithological respect the border between Neweuxinian cover rubbles and upper lied deposits is very contrast. The last ones are different in their structure and genesis. Lower Holocene deposits (Bugaz-Vitiaz) lay the deepest next to the left valley slope and toward the across Paleo-erosion slope the stand shallow. The smallest thickness they have around well 125 . This horizon is represented by alevrites which are light-green, strong sanded with detrital shells of Abra ovata. Also are represented carbonate inserting and in different grade smoothed rubbles in some parts of the cross-section the deposits are in sand facies for instance at well 126 which are obturated sands in gray colour. Bugaz-Vitiaz deposits have deposited in calm, wide, shallow in some places sea basin. It has supposed these deposits mark the beginning of Holocene transgression.

During Kalamit-Djemetin period have deposited the sediments with the biggest thickness. At well 125 the layer is marked in the interval $10,8-23,5 \mathrm{~m}$ and it is representative for the whole cross-section. It is deposited mainly alevrites with variations from clay to sand ones according the places of their sedimentation. At many places the alevrites are organogenious in black color. In different places of this interval are preserved shells from different fauna. The terrigenous material has deposited in calm, fresh or low-tide sea basin. At the end of Djemetin period the deposits have transited from typical marine to lake or firth-lake ones. They mark the end of Kalamit-Djemetin transgression.

Up in the cross-section are tacked the united Upper Holocene, Nymphaean-Fanagorian deposits. They have thickness of 1,9-10,8 $\mathrm{m}$ at well 125 . At the left board of the valley they are with bigger thickness and then toward then right slope become wedge shaped. There are represented alevrites from sand to clay in darkgray to black colour. Often are represented plant remains, shells from bivalvia, gastropods which determine the age of deposits: Hiatella arctica, Donax Trinculus, Chione gallina, Ostrea edulis.

The genesis type of deposits vary from lake, firth, lagoon, mixed to swamp ones depend of sand facies which points the dynamic relation with the sea. 
All sediment complex on the firth are covered by contemporary deposits deposited in alluvial and lake firth conditions. It's thickness is between $1,3-3 \mathrm{~m}$ and the biggest one is near the contemporary bed of Batova river. The deposits are sand alevrites in brown colour and with big quantity plant remains and molluscan shells.

\section{Main development stages}

The analysis of well results points that during Quaternary in development of Batova river could be divided on several stages [4].

The oldest stage is Pre-Neweuxinian one which is a pre-history of the contemporary valley. The absence of older then the Neweuxinian deposits without doubt shows that during this continuous period of time - from Pliocene till the end of Middle Pleistocene the outflow part of the valley have passed several periods of incise and filling. Indirectly this statement is confirmed by the terraces on level $10-15 \mathrm{~m}$ and $35-$ $40 \mathrm{~m}$. For instance on the right valley slope northeastward from Kranevo village on height $3-40 \mathrm{~m}$ are revealed layer of old alluvial rubbles well smoothed with manifold petrographic composition. According their hypsometric position they can be refer to the Middle Pleistocene.

According [2], [4] during the Karangatian transgression the outflow part of Batova river was sea bay. The second stage - Neweuxinian one has begun with intensive erosion rehash of the valley bed due the sharply lowering of the erosion basis during the Post-Karangatian transgression. It have done erosion at all PreNeweuxinian deposits and partially for Upper Miocene sediments.

Obviously some rising of the sea level at the end of this stage has led to deposit of bed alluvium represented by different smoothed limestone rubbles and gravels with clay-sand filler.

At lithological aspect the border between this basalt Neweuxinian alluvium and the upper Holocene deposits is very contrast. The last ones are distinguished in their structure and genesis. In the position of laying Neweuxinian alluvial deposits (Fig. 1) could be pointed a consequently displacement of river bed toward the northern valley slope. In addition the hypsometry of these deposits confirms the statement of Popov and [2] for presence of two buried terraces.

The third stage - Lower Holocene stage marks the beginning of the Flander transgression. During this time the outflow part has filled intensively with mainly fine - dispersed organogeneous-terrigenous material and big quantity plant remains. Periodically into the water catchment has intruded sea water and the prove are finds of fresh water gastropods as and typical marine molluscan. During the time with increasing the transgression temp the influence of the sea water has increased and at the middle of the Middle Holocene the firth-lagoon mode of sedimentation changed to marine one.

During the fourth (Kalamit-Djemetin) stage the examined part of the valley was deep-bay which incise into it on $5 \mathrm{~km}$, maybe more. During this stage in the bay has deposited mainly alevrits and plant detritus. The presence of some fresh water molluscas forms (Dreissena polymorpha) is mark for some refreshment of the sea water.

The fifth - Fanagorian stage is marked by the change of the sea conditions of sedimentation and establish of stasis firth-lagoon and alluvial conditions. The last ones have been disseminated. During this stage has formed the first over-flooded terrace. In it's cross-section are marked two periods: the first period refers to the change of marine mode to firth one. The second period refers to the change of alluvial-lake flood conditions to stasis ones with trend of shallow water and drying.

In the sixth last stage has formed the contemporary face of Batova river valley. It has formed the Nymphaean and wide flooded terrace, sand spit etc.

\section{Conclusions:}

The most important regularities in geomorphology of Batova river firth and it's outflow parts can be reduced to the followed:

1. Depends of the stage of it's development Batova river firth can be referred to the old firth on North Bulgaria Black Sea coast together with Bolata dere, Kamchia and Dvoinishka rivers firths. Contemporary ones are Durankulak, Shabla - Ezerazevo, Varna-Beloslav, Fandakliiska and Vaya river firths. They are distinguished with different morphological expressed sand spit.

2. Batova river firth as the other firths lays in structural depression and over-excavated valley. It is formed in over-excavated part of Batova and Kranevo river valleys.

3. The main regularities in stages of firth development are conditioned by fluctuations of the sea level after Upper Miocene.

4. The oldest deposits in Batova river firth are Neogene and the youngest ones are from Holocene.

5. In the firth the erosion period are represented as over-excavations. 


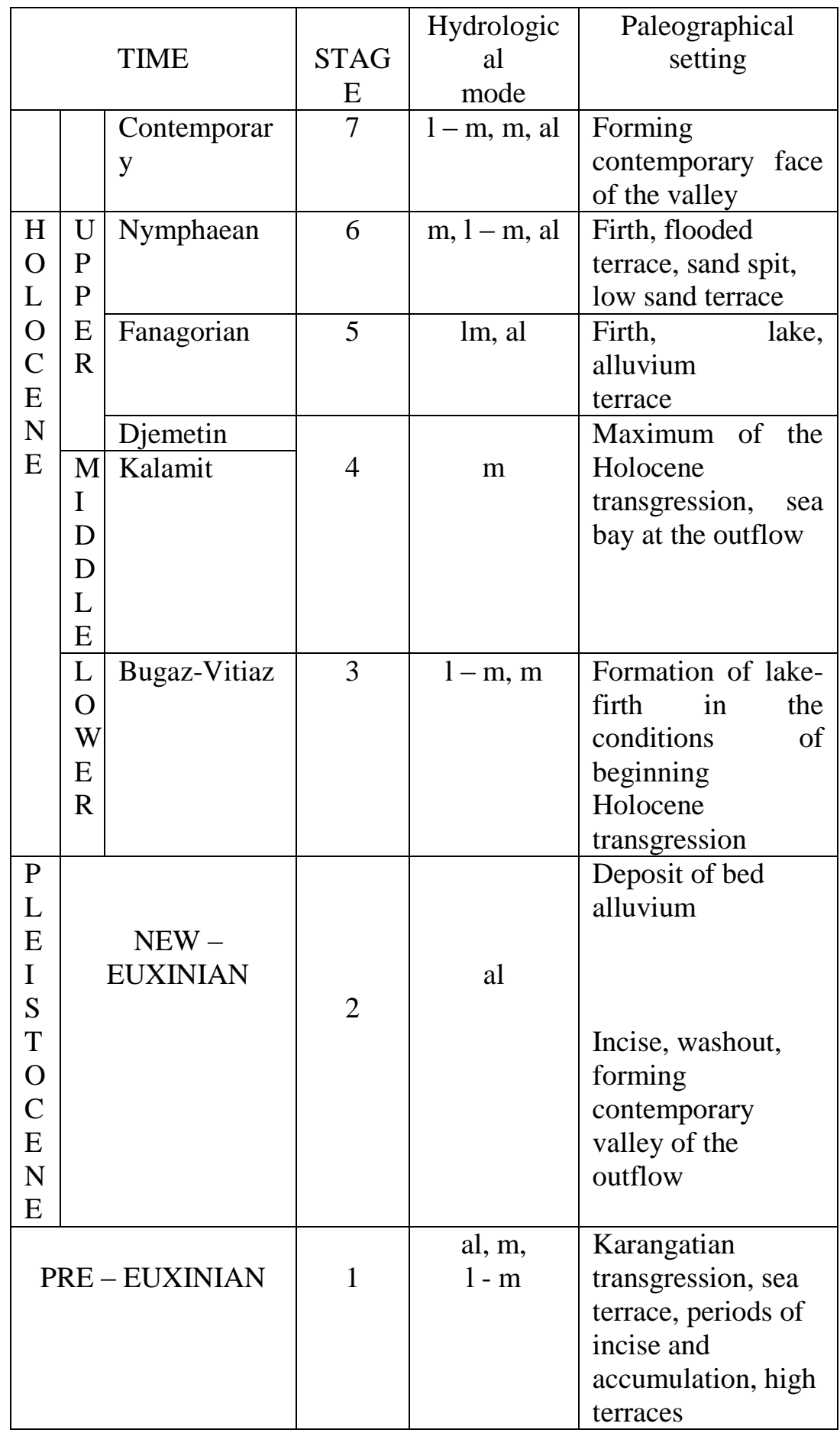

Fig. 1 Diagram of developing Batova river firth

\section{References:}

[1] Kristev, T., O. Parunin, A. Svitoch. Radiouglerodnaya hronologia noveyshih otlozheniy poberezhyya i shelyfa bolgarskogo sektora Chernogo morya. - V: Geologicheskaya эvolyutsia zapadnoy chasti Chernomorskoy kotlovinbl v neogen-chetvertichnoe vemya. S., BAN, 1990, 202-210

[2] Popov, V., K. Mishev. Geomorfologia na balgarskoto chernomorsko kraybrezhie i shelf. S., BAN, 1974, $266 \mathrm{~s}$.

\section{8}


[3] Fedorov, P. V., D. A. Lilienberg, Vl. Popov. Novыe dannыe o terrasah Chernomorskogo poberezhyya Bolgarii. - Dokl. AN SSSR, 1962, 144, 2

[4] Krastev, T. Strukturno geomorfolozhko razvitie na konti-nentalnata okraynina ot balgarskia sektor na Cherno more, Disertatsionnen trud, 1993. 